\title{
Intermédialités
}

Histoire et théorie des arts, des lettres et des techniques

Intermediality

History and Theory of the Arts, Literature and Technologies

\section{How to Watch the Story of Film Adaptation}

Cortázar, Antonioni, Blow-Up ["Raconter / Telling", no 2 automne 2003]

\section{James Cisneros}

Numéro 20, supplément, automne 2012, printemps 2013

traverser

crossing

URI : https://id.erudit.org/iderudit/1023529ar

DOI : https://doi.org/10.7202/1023529ar

Aller au sommaire du numéro

Éditeur(s)

Revue intermédialités (Presses de l’Université de Montréal)

ISSN

1705-8546 (imprimé)

1920-3136 (numérique)

Découvrir la revue

Citer cet article

Cisneros, J. (2012). How to Watch the Story of Film Adaptation: Cortázar, Antonioni, Blow-Up ["Raconter / Telling", no 2 automne 2003]. Intermédialités / Intermediality, (20), 121-136. https://doi.org/10.7202/1023529ar 


\title{
How to Watch the Story of Film Adaptation
}

\author{
Cortázar, Antonioni, Blow-Up
}

\section{James Cisneros}

T

he adaptation of literature to the silver screen has long been considered a privileged topos for comparing different media and, at least potentially, for thinking through the concept of intermediality. When one turns to the filmliterature field for an elaboration of a dialogical and intermedial space, however, one soon finds that the specificity of each medium has been excluded from the relationship supposed to take place between them. Critics see the media in perspective, their receptive positions in the cultural field eclipsed by an institutional gaze that overlooks their mediative role in the transition and transmission of the texts they place in relation.

A cursory look at how studies in the film-literature field approach adaptation is not without heuristic value. Their first step entails close scrutiny of the narrative elements that have been altered, excluded, or embellished in the translation of a literary work to the cinema. Surveying the synopsis of narrative differences between printed text and film, the critic proceeds to trace the contours and inner complexities of each medium. Within this common matrix, the two media are defined negatively on the basis of a narrative that exists in neither rendition, a virtual narrative that is comprised of, and reconciles, the differences between the actual narratives that are materially present to the receptor. As such, the media are fixed and unchanging vessels to which the ideal and transcendent narrative accommodates itself in its passage into actuality, receptacles that may vary slightly in their internal form but which are ultimately contingent to the events that are told. Accordingly, the very notion of "adaptation" implies the mobility of the narrative and the stability of the medial context. ${ }^{1}$

1. While a more focused study of the critical work on adaptation, which is legion, is impossible here, readers will find examples of narrative-based studies in the following 
In these studies, narrative functions as a generic tool that divides literature off from film by underlining one medium's limitations in relation to the other's potential. It takes on all the weight of mediation instead of being one element of an operation that also includes the media's technical supports, their socio-political reach (to literate or non-literate groups, for instance), and their relative institutionalization. Narrative priority neutralizes the medium as a field of action, a middle ground, obscuring the degree to which it participates in the formulation of a story, or the degree to which we read it as much as we do the content it is purported to communicate. This nearly exclusive stress on narrative paradoxically effaces the inter-media it originally set out to explain. Briefly, it loses sight of what McLuhan has taught us: that the media are dynamic and material techniques and practices that circulate in society the same way stories do, messages that carry their own political and ideological implications. Neither the storyteller nor the narrative exists independently of the medium, and neither can be used as a transcendent anchor towards understanding the cultural landscape.

In these pages, I propose an approach to adaptation that places the technical support at the center of the storytelling process. This entails, first, analyzing the narrative privilege in current studies of adaptation as an institutional impulse to control the visual regime that surfaces with photographic technologies and, second, outlining the challenge that mechanically produced images present to previously established parameters for reception and agency. After probing two texts that serve as an example of adaptation-Antonioni's Blow-Up (1966), and the Cortázar short story upon which it is based-and as a theoretical corpus that works through the problem of adaptation, I rearticulate the transition from text to screen in intermedial terms, as a translation taking place in today's mediasaturated cultural landscape.

Most research on "adaptation" participates in institutional currents that conceive of photographic technology as a continuation of camera obscura perspectivism and see the cinema as a narrative-making contrivance. Despite the disparate function and origin of these two currents, they have worked

works: George Bluestone, Novels into Film. The Metamorphosis of Fiction into Cinema, Berkeley and Los Angeles, University of California Press, 1957, a "classic" and often cited as such; Brian McFarlane, Novel to Film: an Introduction to the Theory of Adaptation, New York, Oxford University Press, 1996; Michael Klein and Gillian Parker (eds.), The English Novel and the Movies, New York, Ungar, 1981. More critical angles come from: Dudley Andrew, "The Well-Worn Muse: Adaptation in Film History and Theory," in Syndy Conger and Janice Welsh (eds.), Narrative Strategies: Original Essays in Film and Prose Fiction, Macomb, Illinois, West Illinois University Press, 1980, p. 34-47; Christopher Orr, "The Discourse on Adaptation," Wide Angle, vol. 6, No. 2, 1984, p. 68-84. 
together to incorporate film and photography into an instrumental conception of the medium, and have provided a framework for distinguishing the seventh art from other media. As with other such divisions in the history of the arts, this orthodox distribution has implications that reach beyond the aesthetic domain. The best example perhaps comes from G.E. Lessing, who, in the opening pages of his famous work on the limits of painting and poetry, reminds his readers that the Greeks subjected the arts to a civil code, and calls for the plastic arts to be closely supervised by the law. ${ }^{2}$ And indeed, film and photography have not only suffered the censorship of their iconic contents, but have also been subjected to strong institutional parameters that have controlled the political potential of their form. Yet this has seldom, if ever, been made an object of deliberation in studies of adaptation.

However, other film scholars have not overlooked the relegation of photographic technologies to established narrative frames and visual modes, and have consistently studied how these standards contain the significance of form. A growing body of work has addressed several dimensions of the efforts to accommodate mechanically produced images to preexisting models for visual culture, profiling how the nature of reception proper to these novel images relates to the models' many instituted layers of political meaning or intent, including bourgeois notions of history and subjectivity. Walter Benjamin argues that photography participates in changes in perception and apperception, and is at once a symptom and a cause of new forms of receptive and productive agency. Because photographs stir and challenge the viewer instead of offering the detached contemplation proper to painting, when they acquire political significance due to their accuracy for establishing historical evidence, captions become obligatory: "Signposts, right ones or wrong ones, no matter." These titles do not point the viewer to this or that element within the image's iconic dimension, in the manner of Alberti's prescribed gestures, but bring the entire receptive mode under the tutelage of literacy. They pin the roving, "stirred" viewer to a fixed perspective.

2. Gotthold Ephraim Lessing, Laocoön: An Essay on the Limits of Painting and Poetry, trans. Edward Allen McCormick, Baltimore, John Hopkins University Press, 1984 [1766], p. 14.

3. I am (of course) referring to "The Work of Art in the Age of Mechanical Reproduction”, trans. Henry Zohn, in Illuminations, New York, Schocken Books, 1969 [1935], p. 217-251. Benjamin regroups the same questions in his essay on Nikolai Leskov, where he shows how the irruption of print into the cultural landscape alters the practices of oral storytelling in the early to mid-19th century, a time that also sees a change in the face of death. See Walter Benjamin, "The Storyteller, Reflections on the Works of Nikolai 
Photography seems to herald the end of a form of artistic agency that masters the image with every stroke of the canvas, an intuition that manifests itself in the earliest considerations of the new technology. Instead of the "continuation of life" that Alberti claims for the perspectivist image, a product of scientific and aesthetic command, the modern image is written under the sign of death, a memento mori that shows its own passing away. Benjamin's reference to the "deadly" daguerreotype conjures a figure frequently found in the discourse on photography to signal the advent of the new visual regime. An intuition of another order of agency, the figure of death traces the limits of the subject's independence before the mirror of nature's neutral mediation. In myriad writings, it indicates the limited control over the new medium's plasticity, the partial loss of agency in relation to the creation of its image, and the withering of the subject at the instance of viewing the image.

An early example comes from Carlyle, who believes Emerson's daguerreotype to originate from the valley of death, and urges his friend to replace it with an image traced by the human hand. ${ }^{4}$ It appears again in Hawthorne, Hardy, and Proust before becoming an object of critical inquiry with André Bazin, who emphasizes the agency of the technical apparatus in producing an image that "embalms time." When the figure of death resurfaces more recently with Roland Barthes, it is "the eidos of photography" that compromises the integrity of a viewing subject who, in an extase photographique, enters into the image. Unlike institutional norms that inscribe photography into the camera obscura tradition, a discourse of mastery over the image, these examples indicate its role as an independent agent in the production of uncanny images that elicit their own ethos of reception, inducing the disintegration of subjective identity. ${ }^{6}$

Leskov," trans. Harry Zohn, in Illuminations, New York, Schocken Books, 1969 [1936], p. 83-109.

4. Carlyle writes these lines in 1846. See Jane Rabb (ed.), Literature and Photography: Interactions 1840-1990, Albuquerque, University of New Mexico Press, 1995, p. 18. According to Martin Jay, Emerson uses the same discourse of death to discuss photography in 1841 .

5. André Bazin, "Ontologie de l'image photographique», in Qu'est-ce que le cinéma?, Paris, Éditions du Cerf, 1975 [1945], p. 9-17.

6. See Roland Barthes, La chambre claire. Note sur la photographie, Paris, Cahiers du cinéma, Gallimard, Seuil, 1980; Jonathan Crary, Techniques of the Observer, Cambridge, Massachusetts, MIT Press, 1992. Elsewhere, I discuss the relationship between agency and the figure of death, as it surfaces in the discourse on photography, in a comparative reading of Bazin and Agamben - see the issue of Cinémas on the "imaginary of the end" (Vol. 13, No. 3, «Imaginaire de la fin», Fall 2003). 
With film, the signposts controlling the reception of technologically produced images become more urgent, taking the form of a narrative structure that determines the significance of each image in relation to those preceding it. Focusing on the advent of classical narrative, Noël Burch shows how an institutional mode of representation gradually aligned the medium with the bourgeois ideology of the victory over death. This mode follows traditions inherited from perspectivist painting and the bourgeois novel, centering the viewer before a linear and causally linked narrative. If the new technologies present shadows from the valley of death, figures that indicate the limits of absolute agency over imaginary production, then the institution's double chore entails endorsing an instrumental notion of the medium to give back "life to those shadows." Narrative structure accomplishes both simultaneously, effacing the medium in the service of specific notions of (artistic) agency that predate the irruption of photographic images into the cultural landscape.

To the degree that studies of adaptation fail to question whether technologically produced images are indeed a continuation of perspectivism, or destined to form the basis of a narrative structure, they contribute to the same institutional thrust that eclipses the median zone where these images interact with literature. Such interpretations reduce the complexity of our visual culture, eliding technology's resistance to prosthetic functionality and omitting the subject's lability before a shifting imaginary horizon. The persistence of the camera obscura model for photo and film betrays Alberti's continued influence over disparate modes of reception. Like studies of adaptation that efface the medium's technical support, Albertian models subordinate technè, the geometry that reproduces "natural vision," the "transparent window," to the didactic ends of the narrative istoria, and orient the image towards a viewing subject that is alone invested with the quality to give it meaning, sense, direction. Taken together, these elements anticipate the detached position granted to the viewer, the monocular perspective and disembodied eye (or "I") of the Cartesian subject. ${ }^{8}$ This visual regime

7. Noël Burch, La lucarne de l'infini. Naissance du langage cinématographique, Paris, Nathan Université, coll. "Fac." "Cinéma et image" series, 1991, p. 12. Also published in English as Life to those Shadows, trans. Ben Brewster, Berkeley, University of California Press, 1990 .

8. Martin Jay, Downcast Eyes, Berkeley, University of California Press, 1994. Jay coins the term "Cartesian perspectivism" to describe a single hegemonic visual regime. See Crary (Techniques of the Observer), on photo's challenge to the tradition aligning of Descartes, perspectivism, and the camera obscura. These are but two examples of a growing critical corpus on Alberti's anticipation of Descartes. 
still holds sway over how we think about photography and film, which have been studied according to a receptive mode that presupposes specific forms of agency, narrative, and reception.

The "virtual narrative" we find in studies of adaptation belongs to institutional relations of subjectivity and visuality that precede the invention of photography. Elaborating an intermedial approach to the dialogue of literature and film means accounting for this institutional drive, and requires developing a conception of narrative that does not efface the technical specificity of the media. Certain fictional texts have begun this questioning, placing the medium's material conveyance at the center of a storytelling process whose mode of reception implicates the viewing subject in its discursive operations. Julio Cortázar's "Las Babas del Diablo" ("The Devil's Drool")9 and Michelangelo Antonioni's Blow-Up both experiment with this kind of "story," which we henceforth distinguish from the "virtual" narrative. In a theoretical manner, each text presents a story that is inextricable from the medium, using a free-indirect discourse that invites receptors to adopt a dual optic capable of discerning both dimensions. In the pages that follow I turn first to Cortázar's short story and then to Antonioni's film, before looking at them together as a case study of how this other form of intermedial adaptation might forge its own receptive practices.

\section{CORTÁZAR AND ANTONIONI}

Cortázar's short story is an allegory of translation. Roberto Michel, a FrancoChilean living in Paris, attempts to tell an experience he has had with a camera on the typewriter he is using to translate a scholarly text from Spanish to French. The cultural-linguistic duality enters "Las Babas" in the ambivalent relation the narrator holds to the two machines. Briefly, the narrator attempts to transpose a yarn that unfolds as follows: first, Michel disrupts an amorous scene when he takes a picture of a couple, a woman and a teen-aged boy, on the île Saint-Louis in Paris. Having blown-up the photo and pinned it to the wall, he becomes aware of occupying the exact position of the camera at the time of the shot. Finally, when the figures in the enlarged photo begin to move, Michel irrationally enters into the image to repeat the prior disruption of the amorous scene, which now

9. Julio Cortázar, "Las Babas del Diablo", in Ceremonias, Barcelona, Seix Barral, 1985 [1959], p. 201-215. Henceforth, references to this text will be indicated by the initials "LB", followed by the page numbers, and placed between parenthesis in the body of the text. All translations are my own. I have chosen to keep the passive voice despite its awkwardness in English, as it is essential to the ambiguity of the speaker. 
includes an old pederast. In the story's "fantastic" moment, when he penetrates into the image, the protagonist also fuses with the camera ["I was nothing but the lens of my camera" (LB, p. 213)], and splits into a storyteller who describes himself as both living and dead.

While the yarn relays the camera's repeated action as it intervenes into an amorous scene, "Las Babas" is more properly about the repetition of the storytelling act, about how a series of events is re-counted. Structured around two storytellers, two machines, or two relations of agency that Michel/the narrator holds to technology, the story is repeatedly disrupted by the intervention of one machine (or voice) into the other's report of the events. The "story to be told" coincides with and derives from the machine, the priority of technology confusing the storyteller with the events and their visual representation: "No one knows who is telling the story, whether it is I or what has happened, or what I'm seeing." (LB, p. 2Oz) The narrator's bifurcation into a living entity who manipulates the typewriter and a dead marionette through whom the camera acts reminds us of the discourse on photography. Relinquishing agency to an apparatus, the viewing subject disintegrates in an ecstatic movement towards the image's embalmed time. The split that occurs due to the interface with the camera manifests itself in the differential speech that forks continuously between the first and third person, a sustained use of the passive voice, and a permanent parabasis that inflects each line with the other's intention. The explicit example in the opening line- "It will never be known how to tell this story, [...] If one could say: I were watching the moonrise, or we is feeling ill"-is in fact implicit in every other phrase. A gloss on Rimbaud's Je est un autre, the split literalizes the translator's double-edged voice to give the narrator a dual view of himself and/as Michel.

This perpetual duality approximates what Bakhtin calls free indirect discourse, which elicits a receptive process that calls for the reader to hear two voices at once, to discern the ironic tones that inflect every word with the voice of another or read quotation marks where they aren't given. ${ }^{\circ}$ His analysis of reported

10. The importance of irony in free-indirect discourse is clear in Mikhail M. Bakhtin and Valentin Volosinov, Marxism and the Philosophy of Language, trans. Ladislav Matejka and Irwin R. Titunik, Cambridge, Harvard University Press, 1973 [1929], p. 133. While Bakhtin develops his thoughts on the "image of a language" primarily in reference to the novel, it can also be applied to the short story, as can heteroglossia and double-edged language. See Mikhail Bakhtin, "Discourse in the Novel," in The Dialogical Imagination, trans. Caryl Emerson and Michael Holquist, Austin, University of Texas Press, 1981 [19341945], p. 259-422. 
speech grounds his notions of heteroglossia and dialogism, as well as his theories on how the social and political mark of a discourse is brought into profile, crystallizing into the "image of a language." The conception of language itself as image corresponds to Bakhtin's emphasis on irony, which is unlike other tropes insofar as its understanding depends on the recognition of its discursive operations as such. Pushing the stylistic category to the center of the text's discursive operations eclipses the events behind a polyvocal resonance that corresponds to the view through the camera in "Las Babas," to a specific receptive practice for a peculiar sort of story.

In "Las Babas," the reader's recognition of the discursive operations as such also calls for a specific form of visual reception, which again derives from the discourse on photography. For Michel all looking is "false" because it "throws us outside ourselves," and can only be redeemed "if one chooses between the gaze and what is seen (el mirar y lo mirado)" (LB, p. 205). Yet the narrator intervenes into this "sermon" on choice and looking, inserting a parenthetical interjection that undermines the possibility of such a singular perspective. ${ }^{11}$ Michel will not overcome the photographic ecstasy through faith in either the subjective gaze or the objectively autonomous events that are seen, since both interior and exterior spaces are perpetually bracketed by another's gaze and voice. The subject cannot reintegrate in correspondence to some pristine, objective "outside" that remains untouched by the intentions of another. Instead, we are left to watch how the others inflect on the image or the word, to observe the other's act of seeing. As the conclusion of "Las Babas" shows, looking is only possible if one chooses to watch the gaze rather than the events, since the gaze provides the conditions of possibility for the events to take place (LB, p. 212). This is what Gilles Deleuze, in his study of free indirect discourse in the cinema, calls "les puissances du faux," a way of seeing that brings the medium back to its own temporal rhythms through a narrative that has become its own object, and where truth is dispersed into a multiplicity of perspectives. ${ }^{12}$

11. The passage reads as follows: "Creo que sé mirar, si es que algo sé, y que todo mirar rezuma falsedad, porque es lo que nos arroja más afuera de nosotros mismos, sin la menor garantía, en tanto que oler o (pero Michel se bifurca fácilemente, no hay que dejarlo que declame a gusto). De todas maneras, si de antemano se prevé la probable falsedad, mirar se vuelve posible; basta quizá elegir bien entre el mirar y lo mirado, desnudar a las cosas de tanta ropa ajena." (LB, p. 205)

12. See Gilles Deleuze's discussion of the modern cinema's story (récit) in the chapter entitled "Les puissances du faux" in Cinéma 2. L'image-temps, Paris, Éditions de Minuit, 1985, p. 192-202. He refers to Pasolini's use of free indirect discourse for film on p. 194 
When Julio Cortázar first saw Blow-Up he had the distinct feeling that Antonioni was "winking" at him, and that they were meeting "above or below their differences." He says this in reference to the film's final scene, when the protagonist's questioning gaze receives no answer other than "the rustle of foliage" as the camera "focuses on the trembling leaves" in the park. ${ }^{13}$ In "Las Babas del Diablo," the trembling leaves signal that the photo has come to life, thus anticipating the extase photographique by which Michel relinquishes the integrity of identity to a bifurcated discourse that writes him as both alive and dead, as both present and taken by the wind. This image of quivering leaves has inspired cinéphiles since the invention of the motion picture, possibly because it signals a way of seeing that is specific to the medium, as Kracauer seems to suggest. ${ }^{14}$ Whether one sees the leaves or whether one sees the wind depends on the mode of reception. Cortázar and Antonioni watch what cannot be seen, choosing the gaze (el mirar) over the objective events (lo mirado)-the gaze makes the events happen, just as the image's contents signify in relation their invisible framing. Cortázar recognizes the trembling leaves as a gaze addressed to him, a wink, either because the content of the shot refers to his own description of cinematic viewing or because he simultaneously recognizes the use of the free indirect discourse that informs his own short story. In either case, he senses the presence of something not given in the image. Perhaps he sees the wind.

In Blow-Up, the image of rustling foliage is a "free indirect point of view shot" that places the viewer in the lapsus between the shot's classical logic, which would attribute it to the protagonist, and the subsequent realization that the camera usurps the gaze from an independent position. An example of the temps mort that punctuates all of Antonioni's work, the shot has no bearing on the film's narrative progression, and instead opens a fissure in the image that reveals the apparatus' role in the story's creation. Applying free indirect discourse to the cinema, Pier Paolo Pasolini elaborates a film theory that gives priority to the

and 200, and compares him briefly to Bakhtin in the following chapter, p. 244. He gives more depth to the comparison of Bakhtin and Pasolini in Cinéma 1. L'image-mouvement, Paris, Éditions de Minuit, 1983, p. 106-107.

13. Julio Cortázar, quoted in Rita Guibert, Seven Voices: Seven Latin American Writers Talk to Rita Guibert, trans. Frances Partridge, New York, Knopf Publishers, 1973 [1972], p. 292-293.

14. Siegfried Kracauer, Theory of Film: The Redemption of Physical Reality, Princeton, New Jersey, Princeton University Press, 1997 [1960]. Kracauer cites many eulogies of this image, confessing that the image of a breeze rippling a puddle never left him. See p. xlix, li, 27, 60. 
technical apparatus. Unlike the language of prose, which structures its narratives according to a seamless suturing that hides the camera behind the character's gaze, the language of poetry produces a "pseudo-story" that introduces ruptures into the causal chain of images, making us "feel the camera" in the disparity between its own framing and a character's point of view. ${ }^{15}$ While Antonioni's film is certainly a pseudo-story, it also offers an ironic commentary on the classical, or "virtual," narrative structure, where the sense of one image depends on those preceding it.

In Blow-Up's famous enlargement sequence, Thomas constructs a narrative sequence using the editing codes of classical cinema: the $180^{\circ}$ rule, the shotreverse-shot, etc. He attempts to reproduce the sequence of events that occurred in the park, to "adapt" them into his filmic present by giving the stills classical narrative movement. The adaptation of the stills to his mobile universe means filling the intervals between them with linear causality and making the off-screen space commensurable with the visible terrain. Thomas does this by watching the bodies in the deserted park, searching their gazes for an objective resolution. Following the woman's gaze and the contorted posture of her body, which curls around her companion to look towards the bushes, he discovers a second man with a pistol. The focus on the object of the gaze soon effaces the gaze itself, however, as the causal drive towards the next image makes the off-screen space a verisimilar extension of the on-screen action that attracts the eye. Adopting an objective use of the gaze that focuses on the events (seeing the leaves, not the wind), Thomas fills the interval between the photos with an extended narrative space whose sequence homogenizes the images' off-space (fig. 1).

This is the narrative moment, when Thomas manipulates the medium to make a signifying chain. But Antonioni's frame composition during the blow-up scene repeatedly places Thomas between the enlarged prints, signaling another, non-narrative moment that ironically "sutures" the protagonist into the shotreverse-shot sequence. While this is clear when Thomas faces the photographs, his head swiveling like a tennis fan's as his attention alternates between shots, it is perhaps more evident when the camera dollies behind the photos, shooting Thomas through the interval as he puts on a record or pours himself a drink. His

15. Pier Paolo Pasolini, "Le cinéma de poésie," in L'expérience hérétique. Langue et cinéma, trans. Anna Rocchi Pullberg, Paris, Éditions Payot, coll. “Traces”, 1976, p. 135155. Pasolini offers several examples of the stylistic differentiation between points of view, including the alternation of different lenses, shifting angles on the same object, zoom shots, hand-held camera shots, static shots or sudden jump-cuts. 

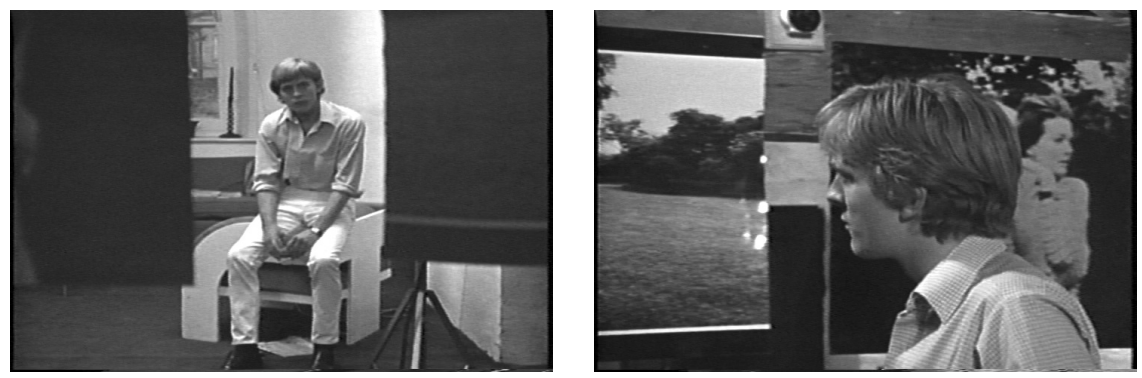

Fig. 1. Michelangelo Antonioni, Blow-Up, 1966 (stills taken from the film).

body fills the interval between the shots, entering the off-screen space towards which the woman in the still image turns, becoming the point of passage for the photo-sequence's narrative time. As we see him fill the interval we also "feel" the camera, watching his gaze through the camera's obtrusive lens as it tracks his movements in the studio. Like the bodily postures he watches, his own gestures become the focus for another gaze that watches the way he looks, a point of intersection for the virtual narrative he constructs and the medium's pseudo-story.

Thomas's role as a switchboard for these heterogeneous strains of narrative circuitry derives from the peculiar quality of his movements. His continuous oscillations between the bustling city and the deserted park follow a pattern Antonioni uses as early as Il Grido (1957), but are complemented here by a freneticism of bodily motions that affects each of the characters who traverse the border between the two spaces-especially Thomas, but also the woman and, of course, the mimes. Thomas's physical frenzy is unrelenting: his heel-tapping, his overly furtive motions while he follows the couple, his bizarre plunge for the telephone, his running, when he leaves the doss house or during the enlargement scene, his incomprehensible struggle for Jeff Beck's broken guitar... While this derives in part from the direction Antonioni gives his actors, focusing on exterior play rather than method acting's introspection, ${ }^{16}$ in Blow-Up the gestures are doubly deliberate, as though to call attention to their own exteriority. The actors' mannerisms and attitudes are not so much gestures that occasionally break an inertial state as

16. Michelangelo Antonioni: "Seul le geste importe pour moi, en lui se résume tout le jeu de l'acteur. Je choisis donc des interprètes qui ont une grande mobilité d'expression et les dirige uniquement de l'extérieur par des indications de gestes et d'attitudes." Cited in René Prédal, Michelangelo Antonioni ou la vigilance du désir, Paris, Éditions du Cerf, 1991, p. 38. 
they are movements that are constitutive of the body-images, icons of a form of motion that is continuous, erratic, and eminently cinematic.

Now, when Thomas enters the interval as part of the effort to give (narrative) movement to the figures in the still photos, it is as though the movement to which Blow-Up continuously subjects his body could be given to the frozen bodily postures in his pictures. In an allegory of modern epistemology, Thomas adapts the still photographs to his own cinematic durée by endowing them with the movement that constitutes him, a quality he projects onto an object that he subsequently recognizes as "life": "I saved a man's life today." (And yet, the wind whistles into the studio, a non-diegetic reminder of another agency and another fate.) Thomas's placement into the photo-sequence's montage interval distinguishes, not without irony, the narrative movement he constructs from the cinematic movement that defines his own body's motions. This is another instance of free indirect discourse, as the viewer first follows Thomas's subjective gaze in the narrative he constructs and then recognizes the objective view of the camera that makes Thomas's entry into the photo-sequence another element of a pseudo-story.

His place between the photos suggests that if he can give (subjective) narrative movement to the sequence at all, it is because he is objectively emblematic of an erratic movement between disparate city and desert spaces. As with all of Antonioni's films, these heterogeneous spaces are mutually exclusive, each one an off-space to the other's on-screen visibility, both overdetermined by their oppositional relation. Thomas's constant vacillating movement derives from this relation and carries within it the border space that gives its sense, following a nomadic trajectory that carries the off-space into the frame. Its cinematic motivation makes the off-screen fuse with the visible terrain, doubling the sense in the solitary image. In contrast to the classical structure that guides the viewer towards the next image and its homogenous hors-champ, this movement extinguishes the image's exterior by making the viewer search each image for the differential view introduced by a double framing. Anticipation of the next image is replaced by a search for the fissure within a single image; classical film's interval yields to the interstice that Deleuze uses to define modern cinema. ${ }^{17}$ When Thomas steps into the photo-sequence's interval, into the off-screen space that drives its causal logic, his body-image simultaneously becomes an interstice of a pseudo-story where we feel the framing of another gaze.

17. See Gilles Deleuze, Cinéma 2. L’image-temps, p. 234-236. 
The photo-narrative's movement has fallen into the invisible threshold above or below its sequential relations. Although Bergson considered photography to be a static, sequential medium that could never capture movement's dynamism, using the proper receptive optic may allow one to find the movement that has fallen above or below the limits of the image's visible stasis. ${ }^{1{ }^{1}}$ "Las Babas" and Blow-Up never cease to point towards thresholds that define this receptive modality. Cortázar's white-faced drooling old man crosses from his cinematic space to the narrator's studio, a diabolic figure who throws apart the unity of the speaker's enunciative space. He prefigures Antonioni's mimes, demonic bodies that play on the border of visibility with their imperceptible tennis ball, itself another instance of the interstitial space towards which Thomas directs his final gesture, having learned to see according to its receptive parameters. And so it is with Blow-Up's final shot, when Thomas disappears from the green void, repeating his entrance into the photo-sequence's interval on the blown-up scale of the film's interstices, disappearing into the modern cinema's irrational fissure (where he can join Dreyer's Gertrud (1964), lost in the faux-raccords).

This crossing over the threshold is the marker, not of off-screen space, but of another gaze in the image or another voice inhabiting the word. It is coherent with the figure of death as we find it in the discourse on photography, connoting a loss of agency, technology's preponderance in the fabrication of sense, and a dual receptive optic. We find its highest expression in the wind, an invisible force that makes the visible penumbra move, the ululating wind that crosses from park to studio and from short story to film, an indiscernible trembling by which Cortázar recognizes Antonioni's gaze as it passes somewhere above or below the threshold of perceptibility.

18. Following Henri Bergson, Gilles Deleuze and Félix Guattari suggest that photographic movement has a speed or intensity that lies just beyond the threshold of perceptibility. It is part of a "devenir-imperceptible": "Si l'on constitue la perception en série, le mouvement se fait toujours au-delà du seuil maximal et en deçà du seuil minimal, dans des intervalles en expansion ou en contraction (micro-intervalles). [...] Il faudrait atteindre au seuil photographique ou cinématographique, mais, par rapport à la photo, le mouvement et l'affect se sont encore réfugiés au-dessus ou en dessous." Gilles Deleuze, Félix Guattari, Mille plateaux. Capitalisme et schizophrénie, Paris, Éditions de Minuit, 1980, p. 344. The sense of "interval" in this passage does not correspond to the sense Deleuze gives it in L'image-temps, but tends more towards the meaning of "interstice" in the later work. See Gilles Deleuze, Cinéma 2. L’image-temps, p. 234-236. 


\section{REVIEWING ADAPTATION}

Having analyzed Cortázar's short story and Antonioni's film as theoretical texts that discuss the irreducible difference between the media, we are left with the question of how they relate to each other. Their point of contact is this: both demonstrate the impossibility of narrative construction for the comparison between media by making the technical apparatus an indispensable element of the story that is told. However, this presents the paradox that "Las Babas" remains a priori heterogeneous to Blow-Up, since one is a printed text, the other a film, and never the twain shall meet. We can speak only of affinities within a shared cultural landscape. But there is something else at work here. While both short story and film highlight the difference between media, they do so by pushing their own discursive operations into the foreground: we see language as an image, we feel the camera. The events and the gaze collapse onto a single, differential plane, with the consequence that neither text provides an exterior space that could provide a ground for comparison.

This loss of an outer space follows from our corpus' own logic. The story entitled "Las Babas del Diablo" and the story produced on the typewriter coincide seamlessly-there is no discursive surplus between what the narrator writes and what we read. Cortázar places language at the center of the series of events he recounts in relation to the narrator, just as the narrator places the camera at the center of the irrational events that he recounts in relation to his double, Michel. The free-indirect discourse running from Michel to the narrator thus contaminates the author's voice; Cortázar's manuscript derives from a machine that has usurped the storyteller's role, making ambiguous the distinction of interior monologue and exterior vision. Nor does the enlargement scene in Blow-Up offer any discursive surplus: the photos completely fill the frame, making the shift in angles a pivotal difference that allows the viewer to "feel" the difference between Thomas's camera and Antonioni's. The apparatus enters into the pseudo-story as one of its formative elements, and the interstice replaces the interval. There is no outside in relation to the layered forms of mediation.

Both case studies of "adaptation" call for an interstitial reading that pivots on the reader's recognition of an ulterior enunciative instance. As in both shortstory and film, where watching the gaze creates the events, to feel the image and hear writing belongs to a process of reception that is a necessary and constitutive element of each text. This receptive priority makes the adaptation of the events witnessed by the camera a false problem, since the reader or viewer can only imagine the photograph, insofar as writing or film codes it according to its own enunciative parameters. It is not that the narrator of "Las Babas" attempts 
to adapt a photo-narrative to a typewritten language, but that the photographic experience is a mere pre-text for the written fiction. Similarly, Thomas's photomontage cannot translate into cinema, since the narrative movement he introduces between stills is overdetermined by Blow-Up's properly cinematic motion. Both short story and film qualify as pseudo-stories precisely because they do not tell a story of something that has happened, but make it happen by placing it in a story that is ultimately about the medium itself. If each pseudo-story is "about" anything at all, it is about the fact that it carries its own conditions of possibility as part of its constitutive expression.

Now, if we are to consider Blow-Up as an adaptation of "Las Babas del Diablo," then we must acknowledge that we are reading the latter into the former as one of its conditions of possibility, and that we subject "Las Babas" to the optic through which we view Antonioni's film. This reading recognizes the specificity of each medium, constituting a text that emerges from the interstice between the modulated short story and the equally modulated film. The receptive mode that hears another's voice in the word or sees another's gaze in the image thus enters a greater comparative process that places the media into a differential or "intermedial" relation. In the story I am telling about this relation, the film and short story's exhaustion of an exterior viewing space repeats itself on the blown-up scale of the media. Their density in defining the cultural moment moves us into its interstices, where we continuously vacillate between inextricable renditions of events that remain lost in the hum of information. Instead of a distant view on stable medial contexts that offer different versions of a virtual narrative, the problem of adaptation provides a pre-text for a reading situation in a differential medial landscape that includes receptors who play a constitutive role in transmission.

Favoring a pre-textual over a contextual reading of adaptation implies that each medium is intermedial insofar as it is partially constituted by, and partially constitutes, the subject of reception. This is far from the institutional relationship where the subject occupies a position of priority from which it surveys the represented ground. The viewing subject ceases to project itself into the disembodied position of Cartesian perspectivism, and is instead incorporated into a storytelling process that plays across perceptive thresholds and registers. The emergent modalities of reception replace the camera obscura's disincarnated eye with an opaque body that is "capable of connecting to other agencies and machines." ${ }^{19} \mathrm{~A}$

19. Jonathan Crary, "Modernizing Vision", in Viewing Positions. Ways of Seeing Film, Linda Williams (ed.), New Brunswick, New Jersey, Rutger's University Press, "Depth of Field” Series, 1995, p. 33. Below, I follow Donna Haraway, Simians, Cyborgs, Women: The Reinvention of Nature, New York, Routledge Press, 1991. 
progeny of the spiritual "medium," the receptive body has become an intersecting locus for the invisible currents that rush over the extended field. Like Thomas or Cortázar's narrator, but on a different scale, the body becomes an intermedial junction, yielding to the apparatus in the medium's interstices. Bakhtin and Pasolini hint at this with their sensory cross-wiring, where we see sounds and feel images, indicating the vestiges of orality that persist in the printed text or the remains of kinesthetic experience that persist in film-signs of intermediality retained in the body. Ours are receptive bodies implicated in a cultural landscape where nothing seems to have changed but the wind, fragile bodies that have been folded into a cyborg network.

Finally, we must add that this receptive mode is as much an individual reading that I have made here, as it is a symptom of the cultural forces saturating us with a media consciousness that challenges the visual regime commonly applied (still!) to film and photographic technologies. At this point we can add that a mode of reading that recognizes the difference between the media as the source of their commensurability is itself contingent to institutional forces that determine what can be read and what "reading" is. That they should bring us together to discuss "intermediality" is precisely what permits me to present you with my reading of Cortázar and Antonioni, and to claim that their focus on the media implicitly theorizes the problem of adaptation. I have told my own story about them, presenting an admixture of imaginative interpretation and of citation from authoritative figures who currently influence academic production. How my text will be read, and how we will manage the expressions of these emergent institutional forces, including the journal you are presently holding, will be partially determinant of what intermediality becomes. Whether it will refer to an in-between from which we survey the media's differences, a hiatus from the onslaught of information, or whether it will refer to a differential space of ubiquitous and ambient mediation that incorporates us into the cultural landscape with varying intensities, remains to be seen. 